\title{
Penerapan Pembelajaran Terpadu Model Integrated Dalam Meningkatkan Minat Dan Prestasi Belajar Bahasa Indonesia Siswa Kelas V-C SD Negeri Beroanging Kecamatan Tallo Kota Makassar
}

\section{The Implementation of Integrated Learning Model to Improve Students' Interest and Achievement in Learning Indonesian Language for Grade V-C Students of SD Negeri Beroanging, Tallo District, Makassar City}

\author{
Arsiah Arsyad ${ }^{1 *}$, Andi Hamsiah ${ }^{2}$, Asdar $^{2}$ \\ ${ }^{1}$ Sekolah Dasar Negeri Beroangin Kota Makassar \\ ${ }^{2}$ Program Studi Pendidikan Dasar, Program Pascasarjana, Universitas Bosowa \\ *E-mail: asiaharsyad111@gmail.com
}

Diterima: 10 September 2021/Disetujui 23 Desember 2021

\begin{abstract}
Abstrak. Tujuan yang ingin dicapai dalam penelitin ini adalah (1) Mendekripsikan peningkatan minat belajar bahasa Indonesia siswa kelas V-C SD Negeri Beroanging Kecamatan Tallo Kota Makassar setelah penerapan pembelajaran terpadu model integrated; dan (2) mendeskripsikan peningkatan prestasi belajar Bahasa Indonesia siswa kelas V-C SD Negeri Beroanging Kecamatan Tallo Kota Makassar setelah penerapan. Pembelajaran terpadu model integrated. Jenis penelitian yang digunakan adalah penelitian tindakan kelas (PTK) dengan menggunakan desain penelitian PTK, yang meliputi: perencanaan tindakan, pelaksanaan tindakan, observasi dan evaluasi, serta refleksi. Hasil penelitian ini menyimpulkan bahwa (1) minat belajar bahasa Indonesia siswa kelas V-C SD Negeri Beroanging Kecamatan Tallo Kota Makassar mengalami peningkatan setelah menggunakan pembelajaran terpadu model integrated. Minat belajar Bahasa Indonesia siswa kelas V-C SD Negeri Beroanging Kecamatan Tallo Kota Makassar mengalami peningkatan setelah menggunakan pembelajaran terpadu model integrated. Hal ini ditunjukkan oleh cepatnya siswa datang ke sekolah; selalu mengerjakan PR; suka mngerjakan soal dan latihan, baik di sekolah maupun di rumah; tidak suka membolos; suka mengulangi pelajaran di rumah; selalu memperhatikan penjelasan guru; aktif bertanya; aktif menjawab; aktif berdiskusi, bersungguh-sungguh dalam belajar, aktif mengerjakan tugas di kelas; aktif bekerja sama dalam belajar; saling melengkapi jawaban dalam diskusi; menjaga sopan santun dan tata krama, serta disiplin dalam bekerja/mengerjakan tugas; dan (2) prestasi belajar bahasa Indonesia siswa kelas V.C - SD Negeri Beroanging Kecamatan Tallo Kota Makassar mengalami peningkatan setelah menggunakan pembelajaran terpadu model integrated, yang ditunjukkan oleh nilai hasil belajar pada siklus I baru mencapai $34,78 \%$ (8 orang) yang mencapai ketuntasan belajar berdasarkan Kriteria Ketuntasan Minimal (KKM) dengan nilai 80, kemudian mengalami peningkatan yang sangat signifikan pada siklus II menjadi $100 \%$ (23 orang siswa). Dengan demikian, pada siklus II tidak ada siswa yang tidak tuntas berdasarkan KKM, sehingga prestasi helajar siswa mengalami peningkatan yang sangat tinggi.
\end{abstract}

Kata Kunci: Pembelajaran Terpadu, Integrated, Minat Dan Prestasi Belajar

\begin{abstract}
The objectives that will be achieved in this research are : (1) to describe the improvement of the students' interest in learning Indonesian language at the grade V-C students of SD Negeri Beroanging, Tallo District, Makassar City using the application of the integrated learning model; and (2) describe the improvement of Indonesian language learning achievement of the grade V-C students of SD Negeri Beroanging, Tallo District, Makassar City using the application of the integrated learning model. This study is classroom action research (CAR), which includes: planning action, action implementation, observation and evaluation, and reflection. The results of this research concludes that: (1) the interest in learning Indonesian language of the grade V-C students of SD Negeri Beroanging, Tallo District, Makassar City, improved after the use of the integrated learning model. This can be seen from the improvement of students' interest and the enthusiasm of students' learning, students' achievement, students' interest in discussing and expressing opinions, students' interest in deepening or expanding to understand the material presented by the teacher, students' interest in reading other books as a support in indonesian language learning, and students' interest in doing assignments or homework; and (2) Indonesian language learning achievement of the grade V-C students of SD Negeri Beroanging, Tallo District, Makassar City, increased after the use of the integrated learning model. This can be seen from the learning outcomes in the first cycle only reaching 34.78\% (8 people) who achieve mastery learning based on the Minimum Completeness Criteria (KKM) with a value of 80, then this figure experienced a significant increase in the second cycle to 100\% (23 students). Thus, in the second cycle there were no students who did not complete based on the KKM, so that the students' learning achievement experienced a dramatically high improvement.
\end{abstract}

Keywords: Integrated Learning, Integrated, Interest And Learning Achievement 


\section{Pendahuluan}

Pendidikan merupakan sebuah proses memanusiakan manusia atau mendewasakan manusia melalui proses sosialisasi dan proses pembiasaanya (pembudayaan). Oleh karena itu, perubahan atau perkembangan pendidikan merupakan hal yang harus terjadi seiring dengan perubahan budaya. Lebih lanjut dikemukakan bahwa pendidikan harus mendukung pembangunan di masa mendatang dengan cara mengembangkan potensi peserta didik, sehingga peserta didik mampu menghadapi dan memecahkan problem hidup yang dihadapinya, sehingga pendidikan itu harus menyentuh potensi hati nurasi dan potensi kompetensi (Agus, 2017).

Pembelajaran Bahasa Indonesia pada semua tingkatan, termasuk juga di sekolah dasar tidak akan terlepas dari empat keterampilan berbahasa, yaitu menyimak, berbicara, membaca, dan menulis. Keempat keterampilan berbahasa tersebut sangat mempengaruhi hasil belajar Bahasa Indonesia. Sekolah dasar merupakan momentum awal bagi siswa untuk kemampuan dirinya. Keterampilan berbahasa yang baik merupakan salah satu keterampilan yang diharapkan dimiliki oleh siswa selama berada pada jenjang sekolah dasar. Menurut Badan Standar Pendidikan Nasional (BNSP, 2006) standar isi Bahasa Indonesia adalah Bahasa Indonesia diarahkan untuk mengembangkan kemampuan peserta didik untuk berkomunikasi dengan bahasa yang baik dan benar secara lisan maupun tertulis serta menumbuhkan apresiasi terhadap hasil karya kesusastraan manusia Indonesia.

Untuk mengatasi permasalahan tersebut, maka diperlukan inovasi dari guru untuk mengemas pembelajaran Bahasa Indonesia agar digemari oleh siswa. Saat mengikuti proses pembelajaran, inovasi yang kreatif sangat diperlukan agar siswa bisa mengikuti proses belajar dengan baik. Salah satu inovasi model pembelajaran yang dapat digunakan agar siswa dapat ikut terlibat aktif dalam proses pembelajaran, sehingga berdampak pada peningkatan prestasi belajar Bahasa Indonesia bagi siswa kelas V-C SD Negeri Beroanging Kecamatan Tallo Kota Makassar adalah menggunakan model pembelajaran terpadu tipe integratif.

Seorang guru Bahasa Indonesia yang profesional perlu memiliki pengetahuan tentang teori belajar bahasa. Di samping itu, guru juga dituntut untuk memiliki pengetahuan tentang konsep bahasa. Brown (dalam Agus, 2017a: 8) ) memberikan batasan atau definisi bahasa adalah (a) bahasa itu sistematis; (b) bahasa adalah seperangkat simbol manasuka; (c) simbolsimbol bahasa, utamanya adalah vokal, tetapi bisa juga visual; (d) simbol mengonvensionalkan makna yang dirujuk; (e) bahasa dipakai untuk berkomunikasi; (f) bahasa beroperasi dalam sebuah komunikasi atau budaya wicara; (g) bahasa pada dasarnya untuk manusia walaupun bisa jadi tidak hanya terbatas untuk manusia; dan (h) bahasa dikuasai oleh semua orang dalam cara yang sama.

Menurut Agus (2017a: 8), ada empat teori belajar bahasa yang perlu dipahami oleh seorang guru Bahasa Indonesia profesional, termasuk di Sekolah dasar (SD), yaitu teori behavioristik, teori kognitif, teori humanistik, dan glossodinamik. Uraian lebih lanjut mengenai teori yang mendasari perlunya belajar bahasa tersebut dapat dilihat di bawah ini.

\section{a. Teori Behavioristik}

Teori belajar bahasa ini bersumber dari seorang ahli jiwa dan biologi, yaitu Ivan Pavlov yang melakukan serangkaikan percobaan yang membuktikan bahwa beberapa aktivitas belajar manusia dihasilkan oleh proses pengontrolan (conditioning). Teori ini menggunakan istilah penting, yaitu Stimulus (S) yang berkaitan dengan aspek fisik lingkungan yang mampu merangsang organ indra; Stimulan alamiah (SA) yang secara alamiah memancing respons; Stimulus terkontrol (SK) yang hanya memancing respons terkontrol jika didempetkan dengan stimulan alamiah; Respon (R) yaitu perilaku yang dipancing oleh sebuah atau serangkaikan stimulan; Respon alamiah (RA) yaitu respon dipancing oleh stimulan alamiah; dan Respon terkontrol (RT) yaitu respon yang dihasilkan oleh stimulan terkontrol sebagai pengganti stimulan alamiah.

\section{b. Teori Kognitif}

Teori kognitif ini memfokuskan diri pada pikiran, ide, dan imajinasi sebagai unit dasar belajar. Pengenalan (kognisi) adalah istilah umum yang digunakan untuk mengetahui cara bernalar, mengingat, melupakan, menandai, menghayati, membayangkan, dan sebagainya. Teori kognitif berkisar tentang pengenalan (kognisi) mencakup pengolahan informasi, persepsi, penyimpanan, dan pemunculan.

Suatu prinsip pokok yang dipegang oleh ahli ilmu jiwa kognitif adalah bahwa pengelanan orang terhadap lingkungannya adalah hasil transformasi yang bukan hanya dilakukan oleh organ indra, tetapi juga oleh struktur kompleks atau sistem yang mengolah, menerjemahkan masukan (input) indra. Orang dipandang sebagai partisipan aktif yang menyeleksi stimulan yang bermakna saja dari lingkungannya. Ada dua teori kognitif tentang belajar yang berpengaruh yaitu teori Piaget dan teori Bruner. Menurut Piaget, terdapat 4 ciri pokok yang mendasari pengenalan (kognisi), yaitu (1) asimilasi, yang merujuk pada situasi yang saatnya informasi ditangkap oleh otak, berpikir bukan saja sebagai suatu fungsi stimulan masukan tetapi juga berfungsi yang sudah ada dalam otak; (2) akomodasi, yang merujuk pada situasi yang saatnya otak mengakomodasi atau mengakumulasi stimulan lingkungan yang masuk; (3) skema, yang merujuk pada satuan struktural kemampuan kognitif dalam kerangka data indria dimasukkan; dan (4) equilibirasi, yang merujuk proses tempat skemata atau struktur kognitif berubah dari satu keadaan ke keadaan lain.

\section{c. Teori Humanistik}

Teori belajar bahasa dengan menggunakan pendekatan humanistik memandang bahwa pribadi anak didik memegang peranan yang sangat penting dalam proses pengajaran bahasa. Teori lebih memfokuskan diri dari segi afektif, bukan psikomotorik atau kognitif. Menurut Rogers sebagai seorang tokoh teori ini adalah seluruh motivasi bertolak dari usaha atau kemauan menuju pembuktian diri dalam bentuk perbuatan, bukan dari insting. Ia beranggapan bahwa semua orang memiliki 
dorongan alamiah untuk membuktikan kemampuannya dan melaksanakan tugasnya secara mandiri. Sifat ini akan tumbuh subur dalam suasana yang baik dan diterima oleh orang lain. Tetapi jika suasan ini rusak, maka orang akan cenderung memilih jalan lain agar terhindar dari ketidakpuasan yang mungkin timbul (Kaseng dalam Agus, 2017a: 13).

\section{d. Teori Glossodinamik}

Glossodinamik adalah suatu teori belajar yang dikembangkan oleh Titone, yang mengintegrasikan Paham behavioristik, kognitif, dan humanistik. Penganjur teori ini beranggapan bahwa belajar bahasa adalah proses dinamis dan memuaskan. Glossodinamik memandang bahwa pengontrolan operan (respon yang bersifat imbalan), penyusunan kognitif, dan dorongan pribadi semua terintegrasi selama orang belajar bahasa. Teori ini mengajukan dua dimensi dasar yang terlibat dalam proses pembelajaran bahasa, yaitu struktur dalam dan struktur luar.

Bahasa Indonesia yang baik adalah bahasa yang digunakan sesuai dengan norma masyarakatan yang berlaku sedangkan Bahasa Indonesia yang benar adalah Bahasa Indonesia yang digunakan sesuai dengan aturan atau kaidah tata Bahasa Indonesia baku. Jadi, Bahasa Indonesia yang baik dan benar adalah Bahasa Indonesia yang digunakan sesuai norma kemasyarakatan yang berlaku dan sesuai dengan kaidah Bahasa Indonesia yang baku. Tanpa adanya pembinaan dan pengembanagan tersebut, Bahasa Indonesia tidak akan dapat berkembang, sehingga dikhawatirkan Bahasa Indonesia tidak dapat mengemban fungsi-fungsinya. Salah satu cara dalam melaksanakan pembinaan dan pengembangan Bahasa Indonesia itu adalah melalui mata pelajaran Bahasa Indonesia di sekolah khususnya di sekolah dasar. Pembinaan dan pengembangan kemampuan dan keterampilan berbahasa yang diupayakan di sekolah berorientasi pada empat jenis keterampilan berbahasa, yaitu keterampilan menyimak, keterampilan berbicara, keterampilan membaca, dan keterampilan menulis. Keempat keterampilan berbahasa tersebut berhubungan erat satu dengan yang lain

Bahasa memiliki peran sentral dalam perkembangan intelektual, sosial, dan emosional peserta didik dan merupakan penunjang keberhasilan dalam mempelajari semua bidang studi. Pembelajaran bahasa diharapkan membantu peserta didik mengenal diri, budaya, dan budaya orang lain, mengemukan gagasan dan perasaan, berpartisipasi dalam masyarakat yang menggunakan bahasa tersebut, dan menemukan serta menggunakan kemampuan analitis dan imajinatif yang ada dalam dirinya.

Pembelajaran terpadu yang diterapkan di sekolah dasar merupakan suatu upaya untuk memperbaiki kualitas atau mutu pembelajaran, terutama dalam rangka mengimbangi gejala penjejalan isi kurikulum yang seringkali terjadi dalam proses pembelajaran yang dilaksanakan di sekolah-sekolah. Penjejalan isi kurikulum itu sangat mengkhawatirkan akan mengganggu perkembangan intelektual dan kematangan sosial anak, karena terlalu banyak menuntut anak untuk mengerjakan aktivitas atau tugas-tugas yang melebihi kapasitas dan kebutuhan mereka.

Model pembelajaran sangat penting digunakan oleh guru dalam proses pembelajaran untuk menciptakan suasana pembelajaran yang menyenangkan, kondusif, dan menciptkan hasil belajar yang memuaskan. Untuk memperleh pemhaman mengenai model-model pembelajaran terpadu yang dapat digunakan oleh seorang guru di Sekolah dasar (SD) dalam proses pembelajaran, maka di bawah ini akan dikemukakan sepuluh model pembelajaran terpadu.

Fogarty sebagaimana dikutip oleh Hernawan dan Rosmini (2017:) mengemukakan 10 (sepuluhh) model dalam pembelajaran terpadu, yaitu (1) fragmented, (2) connected, (3) nested, (4) sequenced, (5) shared, (6) webbed, (7) threaded, (8) integrated, (9) immersed, dan (10) networked.

\section{Metode Penelitian}

Jenis penelitian ini adalah penelitian tindakan kelas (PTK) dengan menggunakan desain penelitian PTK yang diadaptasi dari model Kemmis dan Mc Targgart, yang meliputi: perencanaan tindakan, pelaksanaan tindakan, observasi dan evaluasi, serta refleksi.

Untuk menghilangkan persepsi yang berbeda tentang istilah dalam penelitian ini, maka diberikan defenisi atau batasan istilah yang menjadi titik perhatian dalam penelitian ini. Secara singkat definisi istilah akan diuraikan di bawah ini.

1. Pembelajaran terpadu model intevrated adalah suatu model pembelajaran terpadu yang digunakan dalam pembelajaran bahasa yang berusaha memadukan beberapa mata pelajaran dengan memprioritaskan konsep-konsep, keterampilanketerampilan, dan sikap yang dipadukan dari masing-masing mata pelajaran atau mengaitkan beberapa aspek, baik dalam intra mata pelajaran maupun antar mata pelajaran.

2. Minat belajar yang dimaksudkan dalam penelitian ini adalah semangat atau motivasi belajar dari siswa yang ingin diobservasi, apakah mengalami peningkatan setelah diterapkannya model pembelajaran nested.

3. Prestasi belajar adalah hasil yang diperoleh siswa setelah mengikuti proses pembelajaran. Prestasi belajar yang dimaksudkan di sini adalah berkaitan dengan hasil belajar siswa itu sendiri, apakah ia memperoleh nilai yang baik atau buruk. Apabila siswa pada umumnya memperoleh nilai baik, maka prestasi belajar siswa tersebut dianggap baik pula. Instrumen yang digunakan sebagai alat pengumpul data dalam penelitian ini adalah angket dan tes. Angket digunakan untuk menggambarkan minat siswa, apakah mengalami peningkatan atau tidak ada peningkatan setelah diterapkan model pembelajaran integratif. Angket ini berisi 15 pertanyaan dengan empat (4) opsi jawaban, yaitu sangat setuju, setuju, tidak setuju, dan sangat tidak setuju. Sedangkan tes digunakan untuk mengukur prestasi atau hasil belajar siswa yang terdiri atas 30 item. Perangkat tes itu terlebih dahulu diujicobakan pada kelas V-B atau yang sederajat dengan sasaran penelitian.

Data yang dikumpul akan dianalisis secara kualitatif. Untuk teknik analisis data digunakan statistik deskriptif untuk mendeskripsikan karasteristik responden. Untuk jenis analisis data kualitatif yang digunakan adalah kategorisasi. Kriteria yang digunakan untuk menentukan skor prestasi atau hasil belajar mata pelajaran bahasa Indonesia adalah skala lima. 
Untuk analisis data kualitatif, maka teknis kategorisasi dalam buku laporan pendidikan yang ditetapkan oleh Depdikbud (1996: 6) sebagai berikut:

$\begin{array}{ll}\text { Nilai } 8,5(85)-10,0(100) \text { dikategorikan sangat tinggi } \\ \text { Nilai 6,5 (65) - 8,4 (84) } & \text { dikategorikan tinggi } \\ \text { Nilai 5,5 (55) - 6,4 (64) } & \text { dikategorikan sedang } \\ \text { Nilai 3,5 (35) - 5,4 (54) } & \text { dikategorikan rendah } \\ \text { Nilai 0,0 (00) - 3,4 (34) } & \text { dikategorikan sangat rendah }\end{array}$

Untuk memperoleh nilai kategori di atas, maka digunakan rumus sebagai berikut: Jumlah skor perolehan

Nilai Akhir:

\section{Total Skor}

\section{Hasil dan Pembahasan}

\section{A. Penyajian Hasil Penelitian}

Hasil penelitian yang akan disajikan pada bagian ini merupakan upaya untuk menjawab dua pertanyaan yang telah dikemukakan pada sebelumnya. Karena itu, pada bagian penyajian hasil penelitian ini akan disajikan dua hal pokok yang mengacu pada rumusan masalah, yaitu (1) deskripsi minat belajar bahasa Indonesia siswa kelas V-C SD Negeri Beroanging Kecamatan Tallo Kota Makassar dengan menggunakan pembelajaran terpadu model integrated dan (2) deskripsi prestasi belajar bahasa Indonesia siswa kelas V-C SD Negeri Beroanging Kecamatan Tallo Kota Makassar dengan menggunakan pembelajaran terpadu model integrated. Untuk mendapatkan data yang berkaitan dengan hal pokok pertama, maka digunakan angket dengan responden (siswa) sebanyak 23 orang. Selanjutnya nntuk menjawab hal pokok kedua di atas, maka digunakanlah tes hasil belajar dengan dua kali tes

Berdasarkan uraian di atas, maka hasil analisis angket yang telah dijawab oleh 23 orang siswa sebagai responden atau subjek dalam penelitian ini dapat digambarkan pada Tabel 1. di bawah ini.

Tabel 1 Respon Siswa Kelas V-C SDN Beroanging Kecamatan Tallo Mengenai Minat Belajar Bahasa Indonesia

\begin{tabular}{|c|c|c|c|c|c|c|c|c|c|}
\hline \multirow{3}{*}{ No } & \multirow{3}{*}{ Pertanyaan } & \multicolumn{8}{|c|}{ Respon Siswa } \\
\hline & & \multicolumn{2}{|c|}{$\begin{array}{l}\text { Sangat } \\
\text { Setuju }\end{array}$} & \multicolumn{2}{|c|}{ Setuju } & \multicolumn{2}{|c|}{$\begin{array}{l}\text { Tidak } \\
\text { Setuju }\end{array}$} & \multicolumn{2}{|c|}{$\begin{array}{l}\text { Sangat } \\
\text { Tidak } \\
\text { Setuju } \\
\end{array}$} \\
\hline & & $\mathrm{F}$ & $\%$ & $\mathrm{~F}$ & $\%$ & $\mathrm{~F}$ & $\%$ & $\mathrm{~F}$ & $\%$ \\
\hline 1. & $\begin{array}{l}\text { Saya sampai di sekolah } \\
\text { sebelum jam 07.00. }\end{array}$ & 22 & 95,65 & 1 & 4,35 & - & - & - & - \\
\hline 2. & $\begin{array}{l}\text { Saya suka duduk di } \\
\text { belakang karena jauh dari } \\
\text { pantauan guru. }\end{array}$ & - & - & - & - & 1 & 4,35 & 2 & 95,65 \\
\hline 3. & $\begin{array}{l}\text { Saya tidak pernah } \\
\text { mencontek ketika ulangan } \\
\text { harian. }\end{array}$ & 17 & 73,91 & 6 & 26,09 & - & - & - & - \\
\hline 4. & $\begin{array}{l}\text { Bahasa Indonesia meru- } \\
\text { pakan pelajaran yang sulit } \\
\text { dipahami. }\end{array}$ & - & - & - & - & 3 & 13,04 & 20 & 86,96 \\
\hline 5. & $\begin{array}{l}\text { Saya suka mengerjakan } \\
\text { soal Bahasa Indonesia } \\
\text { meskipun tidak ada tugas } \\
\text { dari guru. }\end{array}$ & 19 & 82,61 & 3 & 13,04 & 1 & 4,35 & - & - \\
\hline 6. & $\begin{array}{l}\text { Saya tidak mengerja-kan } \\
\text { soal Bahasa Indo-nesia, } \\
\text { baik ada tugas maupun } \\
\text { tidak ada tugas. }\end{array}$ & - & - & - & - & 3 & 13,04 & 20 & 86,96 \\
\hline 7. & $\begin{array}{l}\text { Saya selalu mengerjakan } \\
\text { PR Bahasa Indonesia. }\end{array}$ & 17 & 73,91 & 6 & 26,09 & - & - & - & - \\
\hline 8. & $\begin{array}{l}\text { Saya menyisihkan wak-tu } \\
\text { untuk mengerjakan soal } \\
\text { latihan Bahasa Indonesia } \\
\text { di rumah. }\end{array}$ & 2 & 8,70 & 21 & 91,30 & - & - & - & - \\
\hline 9. & $\begin{array}{l}\text { Saya sering membolos } \\
\text { pada jam pelajaran Bahasa } \\
\text { Indonesia. }\end{array}$ & & - & - & - & 3 & 13,04 & 20 & 86,96 \\
\hline 10. & $\begin{array}{l}\text { Saya belajar Bahasa } \\
\text { Indonesia ketika akan }\end{array}$ & - & - & - & - & 5 & 21,74 & 18 & 78,26 \\
\hline
\end{tabular}




\begin{tabular}{|c|c|c|c|c|c|c|c|c|c|}
\hline \multirow{3}{*}{ No } & \multirow{3}{*}{ Pertanyaan } & \multicolumn{8}{|c|}{ Respon Siswa } \\
\hline & & \multicolumn{2}{|c|}{$\begin{array}{l}\text { Sangat } \\
\text { Setuju }\end{array}$} & \multicolumn{2}{|c|}{ Setuju } & \multicolumn{2}{|c|}{$\begin{array}{l}\text { Tidak } \\
\text { Setuju }\end{array}$} & \multicolumn{2}{|c|}{$\begin{array}{l}\text { Sangat } \\
\text { Tidak } \\
\text { Setuju }\end{array}$} \\
\hline & & $\mathrm{F}$ & $\%$ & $\mathrm{~F}$ & $\%$ & $\mathrm{~F}$ & $\%$ & $\mathrm{~F}$ & $\%$ \\
\hline 11. & $\begin{array}{l}\text { menghadapi ujian. } \\
\text { Saya mengulangi pela- } \\
\text { jaran Bahasa Indonesia } \\
\text { setelah pulang dari } \\
\text { sekolah. }\end{array}$ & 20 & 86,96 & 3 & 13,04 & - & - & - & - \\
\hline 12. & $\begin{array}{l}\text { Saya memperhatikan } \\
\text { penjelasan guru tentang } \\
\text { materi Bahasa Indo-nesia. } \\
\text { Saya tidak peduli dengan }\end{array}$ & 19 & 82,61 & 4 & 17,39 & - & - & - & - \\
\hline 13. & $\begin{array}{l}\text { kesulitan pela-jaran } \\
\text { Bahasa Indonesia. } \\
\text { Saya merasa putus asa }\end{array}$ & 3 & 13,04 & 20 & 86,96 & - & - & - & - \\
\hline 14. & $\begin{array}{l}\text { ketika mengerjakan soal } \\
\text { Bahasa Indonesia. }\end{array}$ & - & - & - & - & 2 & 8,70 & 21 & 91,30 \\
\hline 15. & $\begin{array}{l}\text { Saya lebih suka bermain } \\
\text { daripada belajar Bahasa } \\
\text { Indonesia. }\end{array}$ & - & - & - & - & 3 & 13,04 & 20 & 86,96 \\
\hline 16. & $\begin{array}{l}\text { Keadaan kelas yang ramai } \\
\text { membuat saya enggan } \\
\text { untuk mengikuti } \\
\text { pembelajaran Bahasa } \\
\text { Indonesia. }\end{array}$ & & & & & 15 & 65,22 & 8 & 34,78 \\
\hline 17. & $\begin{array}{l}\text { Orang tua saya selalu } \\
\text { mendampingi saya saat } \\
\text { mengerjakan tugas Bahasa } \\
\text { Indonesia. }\end{array}$ & 2 & 8,70 & 20 & 86,96 & 1 & 4,35 & - & - \\
\hline 18. & $\begin{array}{l}\text { Bahasa Indonesia meru- } \\
\text { pakan pelajaran yang } \\
\text { menarik dan menantang. } \\
\text { Saya tidak pernah bertanya }\end{array}$ & 7 & 30,43 & 16 & 69,57 & - & - & - & - \\
\hline 19. & $\begin{array}{l}\text { kepada guru apabila saya } \\
\text { mengalami kesulitan. } \\
\text { Saya tidak pernah }\end{array}$ & & & & & 13 & 56,52 & 10 & 43,48 \\
\hline 20. & $\begin{array}{l}\text { mengerjakan PR Bahasa } \\
\text { Indonesia. }\end{array}$ & & & & & 2 & 8,70 & 21 & 91,30 \\
\hline
\end{tabular}

Berdasarkan Tabel 1 di atas dapat digambarkan bahwa terdapat 22 responden $(95,65 \%)$ yang menjawab sangat setuju bahwa siswa sampai di sekolah sebelum jam 07.00 dan hanya terdapat 1 responden $(4,34 \%)$ yang menjawab setuju, serta tidak ada satu pun responden yang menjawab tidak setuju dan sangat tidak setuju Hal ini menunjukkan bahwa siswa menyadari betapa pentingnya datang ke sekolah lebih awal sebelum dimulai pelajaran sebagai suatu dorongan tersendiri, sehingga minat mereka untuk mengikuti pelajaran bahasa Indonesia tinggi. Dengan minat yang tinggi untuk mengikuti pelajaran bahasa Indonesia, maka tentu hasil belajar juga mengalami peningkatan yang tinggi pula. Hal yang mendorong mereka cepat datang ke sekolah, salah satunya adalah guru melakukan variasi belajar dalam pembelajaran bahasa Indonesia dengan menggunakan pembelajaran terpadu model integrated.

Untuk mempertajam hasil analisis data di atas, maka perlu dukungan data dari hasil observasi (pengamatan) peneliti terhadap aktivitas yang menunjukkan minat siswa terhadap pelajaran Bahasa Indonesia. Ada beberapa aspek (komponen) yang menjadi titik perhatian peneliti dalam kaitannya dengan aktivitas siswa yang menunjukkan minat siswa dalam pelajaran Bahasa Indonesia, antara lain: (1) aktif bertanya, (2) aktif menjawab, (3) aktif berdiskusi, (4) bersungguh-sungguh belajar, (5) aktif mengerjakan tugas di kelas, (6) aktif bekerja sama dalam belajar, (7) saling melengkapi jawaban dalam diskusi, (8) menguasai atau monopoli dalam kegiatan belajar, (9) menjaga sopan santun dan tata krama, dan (10) disiplin dalam bekerja/mengerjakan tugas. Untuk melihat hasil observasi (pengamatan) terhadap aktivitas siswa dari siklus I menuju ke siklus II, maka dapat dilihat pada uraian Tabel 2 di bawah ini.

Tabel 2 Hasil Observasi Mengenai Aktivitas Siswa dalam Belajar Bahasa Indonesia dengan Menggunakan Pembelajaran Terpadu Model Integrated per siklus 


\begin{tabular}{|c|c|c|c|c|c|c|}
\hline \multirow{3}{*}{ No. } & \multirow[t]{3}{*}{ Aktivitas yang Diamati } & \multicolumn{4}{|c|}{ (Pengamatan) } & \multirow[t]{3}{*}{ Keterangan } \\
\hline & & \multicolumn{2}{|c|}{ Siklus 1} & \multicolumn{2}{|c|}{ Siklus 2} & \\
\hline & & $\mathbf{F}$ & $\%$ & $\mathbf{F}$ & $\%$ & \\
\hline 1. & Aktif bertanya & 6 & 26,09 & 15 & 65,22 & \multirow{10}{*}{$\begin{array}{l}\text { Secara umum } \\
\text { mengalami } \\
\text { peningkatan } \\
\text { aktivitas bela- } \\
\text { jar siswa dari } \\
\text { siklus pertama } \\
\text { ke siklus kedua. }\end{array}$} \\
\hline 2. & Aktif menjawab & 8 & 34,78 & 18 & 78,26 & \\
\hline 3. & Aktif berdiskusi & 10 & 43,48 & 21 & 91,30 & \\
\hline 4. & Bersungguh-sungguh belajar & 15 & 65,22 & 23 & 100 & \\
\hline 5. & $\begin{array}{l}\text { Aktif mengerjakan tugas di } \\
\text { Kelas }\end{array}$ & 16 & 69,57 & 22 & 95,65 & \\
\hline 6. & Aktif bekerja sama dalam belajar & 13 & 56,52 & 21 & 91,30 & \\
\hline 7. & $\begin{array}{l}\text { Saling melengkapi jawaban dalam } \\
\text { diskusi }\end{array}$ & 5 & 21,74 & 13 & 56,52 & \\
\hline 8. & $\begin{array}{l}\text { Menguasai atau monopoli dalam } \\
\text { kegiatan belajar }\end{array}$ & 3 & 13,04 & 0 & 0 & \\
\hline 9. & Menjaga sopan santun dan tata karma & 21 & 91,30 & 23 & 100 & \\
\hline 10. & $\begin{array}{l}\text { Disiplin dalam bekerja/menger-jakan } \\
\text { tugas }\end{array}$ & 19 & 82,61 & 23 & 100 & \\
\hline
\end{tabular}

Berdasarkan Tabel 2 di atas, dapat digambarkan bahwa hasil observasi yang telah dilakukan oleh peneliti menunjukkan bahwa siswa aktif bertanya pada siklus I sebanyak 6 orang $(26,09 \%)$ mengalami peningkatan menjadi 15 orang $(65,22 \%)$. Terdapat 9 selisih peningkatannya dari siklus I menuju siklus II atau sekitar 39, $13 \%$, menunjukkan penngkatan aktivitas siswa dalam hal mereka aktif bertanya dalam kegiatan pembelajaran.

Untuk melihat ada atau tidak adanya peningkatan prestasi belajar siswa dengan menggunakan pembelajaran terpadu model integrated ini dari siklus I dan siklus II, maka dapat dilihat pada Tabel 3 di bawah ini.

Tabel 3 Nilai Hasil Tes Bahasa Indonesia dengan Menggunakan Pembelajaran Terpadu Model Integrated

\begin{tabular}{|c|c|c|c|c|}
\hline \multirow[b]{2}{*}{ No. } & \multirow[b]{2}{*}{ Kode Subjek } & \multicolumn{2}{|c|}{ Hasil Tes per Siklus } & \multirow[b]{2}{*}{ Keterangan } \\
\hline & & Siklus 1 & Siklus 2 & \\
\hline 1. & KHT & 80 & 88 & \\
\hline 2. & $\mathrm{LCH}$ & 81 & 89 & \\
\hline 3. & MFT & 78 & 85 & \\
\hline 4. & MSY & 77 & 85 & \\
\hline 5. & MAR & 80 & 88 & \\
\hline 6. & MD & 78 & 86 & \\
\hline 7. & MFD & 80 & 88 & \\
\hline .8 . & MSM & 79 & 85 & \\
\hline 9. & MY & 76 & 87 & Secara umum \\
\hline 10. & MAS & 76 & 85 & mengalami \\
\hline 11. & ND & 78 & 85 & peningkatan nilai \\
\hline 12. & NMA & 75 & 84 & hasil tes belajar \\
\hline 13. & NA & 76 & 84 & dari siklus \\
\hline 14. & NI & 80 & 87 & pertama ke siklus \\
\hline 15. & $\mathrm{PP}$ & 77 & 84 & kedua. \\
\hline 16. & RA & 80 & 88 & \\
\hline 17. & $\mathrm{RZ}$ & 75 & 85 & \\
\hline 18. & RAP & 81 & 89 & \\
\hline 19. & SA & 79 & 85 & \\
\hline 20. & TQ & 76 & 84 & \\
\hline 21. & UFU & 79 & 86 & \\
\hline 22. & $\mathrm{ZF}$ & 78 & 86 & \\
\hline 23. & $\mathrm{AF}$ & 80 & 88 & \\
\hline
\end{tabular}

Berdasarkan Tabel 3 di atas, perolehan nilai kode subjek KHT dari sikulus 1 yakni 80, sedangkan silus II yakni 88. Ada peningkatan nilai hasil belajar sebanyak 8 angka dari silus I ke siklus II, padahal pada siklus pertama saja kode subjek ini sudah tuntas berdasarkan KKM mata pelajaran bahasa Indonesia yakni 80. Demikian pula, kode subjek LCH siklus I dengan perolehan nilai 81 dan siklus II dengan perolehan nilai 89, ada peningkatan nilai 8 dari siklus I menuju ke siklus II. Subjek penelitian ketiga dengan kode MFT dengan perolehan nilai pada siklus I adalah 78 dan siklus II memperoleh nilai 85 . Hal ini menunjukkan bahwa terjadi peningkatan nilai 7 dari siklus I menuju siklus II setelah diterapkan pembelajaran terpadu model integrated.

Untuk mendapatkan gambaran secara utuh mengenai peningkatan hasil belajar dari siklus I menuju ke siklus II setelah diterapkannya pembelajaran terpadu model integrated dalam pembelajaran bahasa Indonesia betrdasarkan hasil analisis data di atas, maka dapat dilihat pada Tabel 4 di bawah ini. 
Tabel 4 Deskripsi Peningkatan Prestasi Belajar Bahasa Indonesia Siswa Kelas V-C SD Negeri Beroanging Kecamatan Tallo Setelah Menggunakan Pembelajaran Terpadu Model Integrated

\begin{tabular}{|c|c|c|c|c|c|c|}
\hline \multirow{3}{*}{ No. } & \multirow{3}{*}{$\begin{array}{c}\text { Deskripsi/Uraian Peningkatan } \\
\text { Prestasi Belajar Berdasarkan KKM }\end{array}$} & \multicolumn{4}{|c|}{ Nilai Hasil Tes Belajar } & \multirow{3}{*}{ Ket. } \\
\hline & & \multicolumn{2}{|c|}{ Siklus 1} & \multicolumn{2}{|c|}{ Sikus II } & \\
\hline & & $\mathrm{F}$ & $\%$ & $\mathrm{~F}$ & $\%$ & \\
\hline 1. & Di bawah Nilai KKM (80) & 15 & 65,22 & - & - & \\
\hline \multirow[t]{2}{*}{2.} & Di atas Nilai KKM (80) & 8 & 34,78 & 23 & 100 & \\
\hline & $\begin{array}{l}\text { Total } \\
\end{array}$ & 23 & 100 & 23 & 100 & \\
\hline
\end{tabular}

Berdasarkan data pada Tabel 4 di atas, dapat digambarkan pada siswa kelas VI C SD Inpres Beroanging Kecamatan Tallo sebagai subjek penelitian yang mendapatkan nilai di bawah nilai KKM yaknu 80, terdapat 15 orang (65,22\%) menunjukkan bahwa masih dominan siswa yang memperoleh nilai belum tuntas pada siklus I, sehingga diperlukan lagi prosuder Penelitian Tindakan Kelas (PTK) untuk melakukan perbaikan pada siklus II dengan prosedur, yaitu perencanaan, pelaksanaan, pengamatan (observasi), serta refleksi dan tindak lanjut. Karena hasil tes siklus I memperlihatkan bahwa hanya terdapat 8 orang $(34,78 \%)$ yang memperoleh nilai tuntas berdasarkan KKM, sehingga diperlukan kerja keras untuk memperbaiki proses pembelajaran dengan menggunakan pembelajaran terpadu model integrated pada siklus II.

\section{B. Pembahasan Hasil Penelitian}

Pembelajaran terpadu model integrated adalah sebuah model pembelajaran yang membantu siswa dalam rangka mengembangkan pemahaman yang lebih luas dan mendalam mengenai struktur pengetahuan sistematis secara bersamaan (integrated) untuk melatih keterampilan berpikir kritis siswa. Model pembelajaran ini sangat tepat digunakan dalam proses pembelajaran di Sekolah Dasar, sehingga dapat meningkatkan hasil belajar siswa.

Pembelajaran terpadu model integrated merupakan model pembelajaran yang memadukan berbagai mata pelajaran di dalamnya (antar mata pelajaran) atau bisa juga antar topik yang terdapat di dalam suatu mata pelajaran tertentu. Untuk lebih jelasnya, pada bagian pembahasan hasil penelitian ini akan membahas dua hal pokok, yaitu (1) minat belajar Bahasa Indonesia siswa kelas V-C SD Negeri Beroanging Kecamatan Tallo Kota Makassar dengan menggunakan pembelajaran terpadu model integrated dan (2) prestasi belajar Bahasa Indonesia siswa kelas VI.C SD Negeri Beroanging Kecamatan Tallo Kota Makassar dengan menggunakan pembelajaran terpadu model integrated.

Berdasarkan uraian di atas, maka salah satu model pembelajaran yang digunakan dan dipilih menurut pandangan peneliti yang paling tepat adalah pembelajaran terpadu model integrated. Berdasarkan hasil analisis data pada bagian sebelumnya, dapat digambarkan bahwa minat belajar siswa kelas V.C SD Negeri Beroanging Kecamatan Tallo dapat dilihat pada setiap indikator. Indikator pertama, yakni siswa sampai di sekolah sebelum jam 07.00. Hasil analisis data menunjukkan respon positif dari siswa, yaitu terdapat 22 responden $(95,65 \%)$ yang menjawab sangat setuju dan hanya terdapat 1 responden $(4,34 \%)$, serta tidak satu pun yang memberikan respon negatif (tidak setuju dan sangat tidak setuju). Data ini menunjukkan bahwa kesadaran siswa mengenai pentingnya datang ke sekolah lebih awal sebelum dimulai pelajaran menjadi motivasi tersendiri, sehingga dapat meningkatkan minat siswa dalam belajar Bahasa Indonesia. Ketika minat siswa sudah tinggi untuk mengikuti pelajaran Bahasa Indonesia, maka tentu prestasi atau hasil belajar siswa juga mengalami peningkatan yang signifikan. Salah satu faktor yang menyebabkan siswa termotivasi untuk cepat datang ke sekolah adalah guru selalu berusaha melakukan variasi belajar dalam pembelajaran dengan menggunakan pembelajaran terpadu model integrated.

Hasil analisis angket untuk butir pertanyaan kedua menunjukkan bahwa pada umunya siswa memberikan respon negatif (tidak setuju dan sangat tidak setuju) dengan pernyataan, yaitu setuju bahwa siswa suka duduk di belakang karena jauh dari pantauan guru. Hal ini dibuktikan oleh 22 responden $(95,65)$ yang menyatakan sangat tidak setuju dan 1 responden $(4,35 \%)$ yang menyatakan tidak setuju, serta tidak ada satu pun responden yang menyatakan setuju atau sangat setuju dengan pernyataan tersebut. Dengan demikian, dapat dikatakan bahwa pada umumnya siswa tidak senang menempati tempat duduk di belakang karena jauh pantauan guru. Hal ini memperlihatkan bahwa siswa menyadari pentingnya duduk di bagian depan dan tidak suka duduk pada bangku bagian belakang, karena dapat mengganggu konsentrasi dalam belajar.

Aktivitas belajar ketiga adalah aktif berdiskusi. Hasil observasi ditemukan bahwa terdapat 10 orang $(43,48 \%)$ yang aktif berdiskusi pada siklus I mengalami peningkatan menjadi 21 orang (91,30\%) pada siklus II. Dengan demikian, aktivitas siswa, terutama aktif berdiskusi mengalami peningkatan pada siklus II. Hal ini berarti pada siklus II umumnya siswa sudah mulai aktif dalam berdiskusi. Demikian selanjutnya, hasil analisis terhadap aktivitas belajar siswa yang keempat, yakni bersungguh-sungguh belajar Bahasa Indonesia menunjukkan bahwa terdapat 15 orang $(65,22 \%)$ pada siklus I, kemudian mengalami peningkatan menjadi 23 orang (100\%) pada siklus II. Dengan demikian, dapat disimpulkan bahwa penerapan pembelajaran terpadu model integrated dapat meningkatkan aktivitas belajar siswa dalam mengikuti proses pembelajaran.

Prestasi belajar juga dapat diartikan sebagai hasil dari usaha atau upaya yang dilakukan oleh siswa setelah mengikuti proses pemhelajaran, sehingga dapat menjadi sukses atau berhasil dalam belajar. Untuk menjadi sukses, maka seorang siswa hatus mampu menghadapi berbagai tantangan, seperti bakat, minat, potensi, kecerdasan atau intelektual, motivasi, kebiasaan, emosi, dan kesehatan, serta pengalaman pribadi dan orang-orang dari lingkungan, seperti tetangga, keluarga, sekolah, komunitas, fasilitas, dan infrastruktur, fasilitas, nutrisi, dan sebagainya. Namun, dalam penelitian ini prestasi belajar hanya 
dibatasi pada hubungan minat dalam pembelajaran dengan menggunakan pembelajaran terpadu model integrated dengan indikator keberhasilannya adalah prestasi belajar siswa.

Berdasarkan urain dan pembahasan yang telah dikemukakan sebelumnya, maka dapat disimpulkan bahwa hipotesis tindakan yang diajukan dalam penelitian ini, yaitu "Jika model pembelajaran integratif diterapkan, maka minat belajar Bahasa Indonesia siswa kelas V-C SD Negeri Beroanging Kecamatan Tallo Kota Makassar dapat meningkat", dinyatakan diterima. Dengan demikian, dapat dikatakan bahwa penerapan atau penggunaan pembelajaran terpadu model integrated dapat meningkatan minat belajar siswa dalam pembelajaran Bahasa Indonesia pada siswa kelas V-C SD Negeri Beroanging Kecamatan Tallo Kota Makassar mengalami peningkatan. Hal ini ditunjukkan oleh meningkatnya minat dan semangat belajar siswa, prestasi belajar siswa, minat siswa dalam berdiskusi dan mengemukakan pendapat, minat siswa untuk memperdalam atau memperluas pemahaman terhadap materi yang disampaikan oleh guru, minat siswa dalam membaca buku-buku lain sebagai penunjang dalam pembelajaran Bahasa Indonesia; dan minat siswa dalam mengerjakan tugas atau PR.

\section{Kesimpulan dan Saran}

Berdasarkan rumusan masalah, tujuan penelitian, penyajian analisis data, dan pembahasan hasil penelitian yang telah dikemukakan sebelumnya, maka dapat ditarik kesimpulan sebagai berikut minat belajar Bahasa Indonesia siswa kelas V-C SD Negeri Beroanging Kecamatan Tallo Kota Makassar mengalami peningkatan setelah menggunakan pembelajaran terpadu model integrated. Hal ini ditunjukkan oleh cepatnya siswa datang ke sekolah; selalu mengerjakan PR; suka mngerjakan soal dan latihan, baik di sekolah maupun di rumah; tidak suka membolos; suka mengulangi pelajaran di rumah; selalu memperhatikan penjelasan guru; aktif bertanya; aktif menjawab; aktif berdiskusi, bersungguh-sungguh dalam belajar, aktif mengerjakan tugas di kelas; aktif bekerja sama dalam belajar; saling melengkapi jawaban dalam diskusi; menjaga sopan santun dan tata karma, serta disiplin dalam bekerja/mengerjakan tugas. Prestasi belajar bahasa Indonesia siswa kelas V-C SD Negeri Beroanging Kecamatan Tallo Kota Makassar mengalami peningkatan yang sangat signifikan dengan menggunakan pembelajaran terpadu model integrated. Hal ini ditunjukkan oleh nilai hasil belajar pada siklus I baru mencapai 34,78 \% (8 orang) yang mencapai ketuntasan belajar berdasarkan Kriteria Ketuntasan Minimal (KKM), kemudian mengalami peningkatan menjadi $100 \%$ (23 orang siswa) pada siklus II.

\section{Daftar Pustaka}

Agus, Muhammad. 2017a. Teori Belajar Bahasa Indonesia. Yogyakarta: YLJK2 Indonesia.

Agus, Muhammad. 2017b. Bagaiman Seharusnya, Kinerja Guru! Yogyakarta: YLJK2 Indonesia.

Ahmad Rofiudin dan Darmiyati Zuhdi (1996). Pendidikan Bahasa dan Sastra Indonesia di Kelas Tinggi. Jakarta: Depdikbud. Arikunto, Suharsimi dkk. 2010. Penelitian Tindakan Kelas. Jakarta: Bumi Aksara.

Depdikbud. 1996. Evaluasi dan Penilaian. Jakarta: Proyek Penilaian Mutu Guru Dirjen Dikdasmen.

Depdiknas. 2012. Kamus Besar Bahasa Indonesia. Jakarta: Balai Pustaka.

Emzir. 2014. Metodologi Penelitian Pendidikan. Jakarta: Rajagrafindo Persada.

eprints.ums.ac.id. Darmawan, R. 2015. Minat Belajar Siswa: Pengertian dan Faktor-faktor yang Mempengaruhinya. Diakses 19 September 2020.

Fathurrohman, Muhammad. 2015. Model-Model Pembelajaran Inovatif. Yogyakarta: Ar-ruz media.

Jainuddin, J., Mubarik, M., \& Bahri, S. (2021). Pengaruh Metode Pakem Dalam Meningkatkan Motivasi Belajar Siswa Kelas V Sd Negeri 124 Batuasang. Jurnal Ilmiah Ecosystem, 21(1), 186-193.

Julianti, Hefin Dwi Rivai dkk. 2014. Eksperimentasi Model Pembelajaran Nested dan Think Pair Shared (TPS) dengan Pendekatan Kontekstual pada Mata Materi Pokok Bangun Ruang Sisi Datar Ditinjau dari Kecemasan Belajar Matematika Siswa Kelas VIII MTs Ponorogo Tahun Pelajaran 2013/2014. Jurnal Elektronik Pembelajaran Matematika, Vol. 2, No. 8, Oktober 2014.

Junus, A. M. \& Fatimah J., Andi 2012. Pembentukan Paragraf Bahasa Indonesia Kabupaten Gowa: Badan Penerbit UNM Komalasari 2013.Pembelajaran Kontekstual Konsep dan Aplikasi. Bandung: Refika Aditama.

Komara, Endang. 2014. Belajar dan Pemebelajaran Interaktif. Bandung: Refika Aditama

Krisdiyanti, Dewi, dkk. 2019. Pengaruh Model integrated Berbantu Mind Mapping terhadap Hasil Belajar Mimbar PGSD Undiksha, Volume 7 No. 2 Tahun 2019.

Kusuma, Rt. Maharani dkk. 2015. Penerapan Pembelajaran Terpadu Tipe Nested (Tersarang) untuk Meningkatkan Literasi Sains Siswa pada Konsep Ekosistem di Kelas X SMA Negeri 5 Kota Cireben. Jurnal Scientiae Educatia, Volume 5 Nomor 2 Tahyn 2015.

Prestasi Pustaka Publisher.

Trianto. 2014. Model Pembelajaran Terpadu: dalam Teori dan Praktek. Jakarta:

Wanelly, Widya dan Fitria, Yanti. 2019. Pengaruh Model Pembelajaran Integrated dan Keterampilan Berpikir Kritis terhadap Hasil Belajar IPA. Jurnal Basicedu Volume 3, No. 1 Tahun2019 